\title{
BLASTOCYST SURVIVAL IN OVARIECTOMIZED RATS
}

\author{
G. DALE BUCHANAN*
}

\author{
Department of Anatomy, University of Tennessee Medical Units, Memphis, Tennessee
}

(Received 17th Fune 1968, revised 27th September 1968)

\begin{abstract}
Summary. Implantation did not occur at the usual time in rats ovariectomized on Days 1,2,3 or 4 post coitum (p.c.), but could be induced subsequently by injections of progesterone and oestrone, begun in some instances as late as Days 12, 14, 18 and 8 p.c., respectively. Normal numbers of implantation sites were found in most animals when injections were begun on or before Day 8 p.c. Thereafter, the number of rats with implantation sites and the number of sites observed in each rat declined. The interval after ovariectomy during which blastocysts were recovered from rats not receiving hormones corresponded with the period when implantation could be induced, suggesting that blastocysts remained viable for as long as they survived.
\end{abstract}

\section{INTRODUCTION}

Ovariectomy during the first days of pregnancy prevents implantation in rats. However, when progesterone is administered daily from the time of operation viable blastocysts are maintained in the uterus for long periods, and implantation can be elicited when desired by a suitable combination of oestrogen and progesterone (Chambon, 1949; Canivenc \& Laffargue, 1957; Cochrane \& Meyer, 1957). Recent evidence suggests that implantation does not occur in ovariectomized rats receiving progesterone alone because of endometrial incompetence (Dickmann \& De Feo, 1967).

In pregnant ovariectomized rats not receiving hormone therapy, neither cell division nor oviduct transport of the conceptuses is affected (Alden, 1942) and morphologically normal blastocysts enter the uterus at the expected time (Alloiteau \& Psychoyos, 1966), but there is some uncertainty concerning the ability of blastocysts to survive in the uteri of such animals. Cochrane \& Meyer (1957) and Meyer \& Nutting (1964) did not obtain implantation in rats ovariectomized on Day 2 p.c. when injections of $1 \mu \mathrm{g}$ oestrone $+4 \mathrm{mg}$ progesterone were begun 6 days later. In contrast, Canivenc \& Laffargue (1957) performed ovariectomies on Day 3 p.c. and obtained implantation in $63 \%$ and $45 \%$ of the rats which began receiving injections of $10 \mathrm{i}$.u. oestrogen $+10 \mathrm{mg}$ progesterone 7 and 10 days later, respectively. Other workers in the same laboratory achieved comparable results with ovariectomized-adrenalectomized rats (Mayer, Thévenot-Duluc \& Meunier, 1958). It has been suggested that the disparity between the findings described above was due either to strain differences or to

* Present address: Medical College of Ohio at Toledo, Toledo, Ohio 43614, U.S.A. 
the fact that ovariectomy was performed on different days after mating (Mayer, 1963; Nutting \& Meyer, 1963).

The experiments reported below were designed to determine the effect of the day of ovariectomy and the interval of hormonal deprivation on blastocyst survival and viability in mated ovariectomized rats.

\section{MATERIALS AND METHODS}

Nulliparous rats, purchased from the Holtzman Company, were placed on a daily regime of $14 \mathrm{hr}$ light and $10 \mathrm{hr}$ darkness which was maintained throughout the experiment. Water and a standard laboratory diet were continuously available. Females weighing 180 to $200 \mathrm{~g}$ were caged with fertile males and examined each morning for spermatozoa in the vagina. The day when spermatozoa were found was designated Day 0 of pregnancy. Mated rats were isolated and on the afternoon of either Day 1, 2, 3 or 4 post coitum (p.c.) they were anaesthetized with ether and bilaterally ovariectomized by a lumbodorsal approach. Surgery (and subsequently, autopsy) was performed under a binocular dissecting microscope.

At autopsy, all animals were checked for residual ovarian tissue and discarded if any was found. Uteri were weighed and the number and condition of any implantation sites recorded. Uteri without implantation sites were flushed with normal saline and the flushings examined for blastocysts under a compound microscope.

One group of 159 rats received subcutaneous injections of $1 \mu \mathrm{g}$ oestrone +4 $\mathrm{mg}$ progesterone in $0.2 \mathrm{ml}$ corn oil for a period of 5 days, starting on the days indicated in Table 1. The day after the last injection, they were killed and autopsied. A second group of 88 rats, which received no hormones, were killed at the times shown in Table 2.

\section{RESULTS}

Table 1 shows that blastocysts remained viable for several days in the uteri of ovariectomized rats. While the limits of viability were extended by performing ovariectomy on successively later days, implantation was induced in rats ovariectomized on Day 4 p.c. only if hormone injections began within 4 days of the operation.

When hormone administration commenced on or before Day 8 p.c. implantation occurred in most rats ovariectomized on Days 2, 3 and 4 p.c. The number of implantation sites per implanted animal was within the normal limits, although decreases were noted in some rats in which hormone treatment did not begin until Day 8 p.c. Even if hormone administration was begun immediately, implantation occurred in fewer rats ovariectomized on Day 1 p.c. than might have been expected by chance. Since the ova were still in the upper part of the oviduct on Day 1 p.c., this result was probably due to surgical trauma. However, in those animals in which implantation occurred, the average number of implantation sites was normal. Regardless of the day of ovariectomy, the number of rats with implantation sites and the number of sites per animal decreased sharply when injections were begun on Day 10 p.c. or later. 
Table 2 shows that the interval during which blastocysts were recovered from the uteri of ovariectomized rats not receiving hormones corresponded almost exactly with the limits of blastocyst viability shown in Table 1 . The numbers of blastocysts recovered were not included in Table 2 since technical limitations made it difficult to ensure that recovery was complete, and a relatively small error in recovery could yield a highly misleading impression. It was possible to

\section{TABLE 1}

EFFECT OF THE DAY OF OVARIECTOMY AND THE INTERVAL BEFORE THE BEGINNING OF HORMONE TREATMENT ON INDUCTION OF IMPLANTATION IN THE RAT

\begin{tabular}{c|c|c|c|c|c|c|c|c|c|c|c}
\hline $\begin{array}{c}\text { Day of } \\
\text { ovariectomy } \\
(\text { p.c. })\end{array}$ & \multicolumn{8}{|c}{ Day p.c. when hormone injections $s^{\mathrm{a}}$ were begun } \\
\cline { 2 - 9 } & Ovariectomized $^{\mathrm{b}}$ & Day 6 & Day 8 & Day 10 & Day 12 & Day 14 & Day 16 & Day 18 \\
\hline Day 1 & $4 / 6(4)$ & $2 / 4(6)$ & $2 / 5$ & $(7)$ & $2 / 6$ & $(2)$ & $2 / 5(2)^{*}$ & $0 / 4$ & $0 / 4$ & $0 / 5$ \\
Day 2 & $3 / 3(6)$ & $3 / 4(7)$ & $3 / 4$ & $(3)$ & $6 / 12(4) \dagger$ & $1 / 6(1)$ & $1 / 6(1)$ & $0 / 4$ & $0 / 4$ \\
Day 3 & $4 / 4(7)$ & $4 / 4(9)$ & $7 / 10(5)$ & $4 / 8$ & $(2)^{*}$ & $2 / 9(2)^{*}$ & $3 / 7(2)$ & $0 / 4$ & $1 / 3(1)$ \\
Day 4 & $3 / 4(9)$ & $2 / 3(9)^{*}$ & $2 / 3$ & $(8)$ & $0 / 3$ & & $0 / 4$ & $0 / 4$ & $0 / 4$ & $0 / 3$ \\
\hline
\end{tabular}

Figures represent number of animals with implantation sites/total number of animals receiving injections. Average number of implants in each animal with implantation sites shown in parentheses.

* $1 \mu$ g oestrone $+4 \mathrm{mg}$ progesterone/day for 5 days.

b These animals received hormone injections on the day after ovariectomy.

* Resorption occurring in one animal.

$\uparrow$ Resorption occurring in two animals.

\section{TABLE 2}

INFLUENCE OF DAY OF OVARIECTOMY AND POST-OPERATIVE INTERVAL ON BLASTOCYST SURVIVAL AND UTERINE WEIGHTS

\begin{tabular}{|c|c|c|c|c|c|c|}
\hline \multirow{2}{*}{$\begin{array}{c}\text { Day of } \\
\text { ovariectomy } \\
(\text { p.c. })\end{array}$} & \multicolumn{6}{|c|}{ Day of autopsy (p.c.) } \\
\hline & Day 8 & Day 10 & Day 12 & Day 14 & Day 16 & Day 18 \\
\hline Day 1 & $\begin{array}{c}2 / 4 \\
(134 \cdot 4)\end{array}$ & $\begin{array}{c}2 / 4 \\
(123 \cdot 8)\end{array}$ & $\begin{array}{c}1 / 4 \\
(131 \cdot 8)\end{array}$ & $\begin{array}{c}0 / 4 \\
(106 \cdot 1)\end{array}$ & $\begin{array}{c}0 / 4 \\
(117 \cdot 5)\end{array}$ & $\begin{array}{c}0 / 4 \\
(101.8)\end{array}$ \\
\hline Day 2 & $\begin{array}{c}3 / 4 \\
(161 \cdot 4)\end{array}$ & $\begin{array}{c}1 / 4 \\
(138.5)\end{array}$ & $\begin{array}{c}1 / 4 \\
(129 \cdot 1)\end{array}$ & $\begin{array}{c}1 / 4 \\
(114 \cdot 6)\end{array}$ & $\begin{array}{c}0 / 4 \\
(91 \cdot 2)\end{array}$ & $\begin{array}{c}0 / 4 \\
(92 \cdot 2)\end{array}$ \\
\hline Day 3 & $\begin{array}{c}2 / 4 \\
(171 \cdot 1)\end{array}$ & $\begin{array}{c}3 / 4 \\
(171.9)\end{array}$ & $\begin{array}{c}3 / 4 \\
(151 \cdot 5)\end{array}$ & $\begin{array}{c}2 / 4 \\
(117 \cdot 6)\end{array}$ & $\begin{array}{c}2 / 4 \\
(129 \cdot 2)\end{array}$ & $\begin{array}{c}1 / 4 \\
(104 \cdot 3)\end{array}$ \\
\hline Day 4 & $\begin{array}{c}3 / 4 \\
(261.9)\end{array}$ & $\begin{array}{c}2 / 4 \\
(211 \cdot 3)\end{array}$ & $\begin{array}{c}0 / 4 \\
(123 \cdot 8)\end{array}$ & $\begin{array}{c}0 / 4 \\
(141 \cdot 2)\end{array}$ & & \\
\hline
\end{tabular}

Numbers represent number of animals with blastocysts/number of animals examined. Numbers in parentheses represent average uterine weights in mg.

obtain an estimate of the number of blastocysts which could be recovered at any particular time after ovariectomy since this corresponded approximately with the number of implantation sites which could be induced. Uterine weights declined steadily after ovariectomy but there was no correlation between uterine weights and the presence or absence of blastocysts. Not included in Table 2 are data from four rats which were ovariectomized on Day 5 p.c. and killed on Day 8 p.c. The average weight of the uterus in these animals was $296 \cdot 1 \mathrm{mg}$ and 
each uterus contained an average of eight implantation sites, which were already undergoing resorption.

\section{DISCUSSION}

These data indicating that blastocysts remain viable for some time in the uteri of ovariectomized rats not receiving hormones agree with the findings of Canivenc \& Laffargue (1957), but not those of Cochrane \& Meyer (1957) and Meyer \& Nutting (1964) in which implantation was elicited only if maintenance doses of progesterone were begun immediately after ovariectomy. The reasons for this lack of agreement are obscure since the strain of rats used and the hormone doses employed in the present study were the same as those reported by Meyer and his co-workers.

In these experiments, blastocyst viability and survival after ovariectomy appear to be closely correlated since the ability to recover blastocysts from rats not receiving hormones was closely related temporally to the ability to induce implantation. Smithberg \& Runner (1960) have obtained somewhat different results in prepuberal, but sexually competent, mice. They recovered blastocysts from ovariectomized mice as late as Day 46 p.c., but could induce implantation no later than Day 31 p.c. Weitlauf (1968) has recovered blastocysts from ovariectomized adult mice 35 to 40 days p.c., but found Day 30 p.c. to be the limit of viability as determined by blastocyst transfer to pseudopregnant recipients.

Not unexpectedly, the day of ovariectomy affected blastocyst survival. The increased survival in animals ovariectomized on Day 3 p.c. probably reflects the increased interval of pre-operative uterine development due to ovarian hormones, particularly progesterone. The relatively brief survival of blastocysts in rats ovariectomized on Day 4 p.c. and the transient implantation after ovariectomy performed on Day 5 p.c. are consistent with the report of Mayer (1963) that spaying rats on Days 4 and 5 p.c. caused a prompt termination of pregnancy. The pontamine blue reaction, indicative of increased uterine vascular permeability, becomes positive on Day 4 p.c. (Psychoyos, 1960) and it is probable that although the blastocysts are not yet attached to the endometrium, implantation is already underway in a physiological sense. Since pregnancy is quickly terminated in most species by ovariectomy during the early postimplantation period (Deanesly, 1966), these results of ovariectomy on Days 4 and 5 p.c. are not surprising.

While the physiological state of the uterus unquestionably determines the limits of blastocyst survival, the ability to induce implantation is relatively unimpaired until Day 8 p.c. regardless of the day of ovariectomy. Subsequently, both the average number of implantation sites and the proportion of the rats with implantation sites decreases, implying that blastocysts perish individually rather than in groups as has been reported in mice (Smithberg \& Runner, 1960). The data suggest that intrinsic factors, presumably metabolic, enable the rat blastocyst to remain relatively autonomous during the first week, after which competition for available uterine resources limits both the number of blastocysts and the length of their survival. 


\section{ACKNOWLEDGMENTS}

The excellent assistance of William Lloyd Glover (presently Captain, Medical Corps, U.S. Army) in conducting these experiments and funds from the General Research Support Fellowship Grant FR-05423, which made his participation possible are gratefully acknowledged. This investigation was supported by Public Health Service Grant HD-00504, from the National Institute of Child Health and Human Development.

\section{REFERENCES}

ALDEN, R. H. (1942) Aspects of the egg-ovary-oviduct relationship in the albino rat. F. exp. Zool. 90, 159.

Alloiteau, J. J. \& Psychoyos, A. (1966) Y a-t-il pour l'œuf de ratte deux façons de perdre sa zone pellucide? C.r. hebd. Séanc. Acad. Sci., Paris, 262, 1561.

Canivenc, R. \& Laffargue, M. (1957) Survie des blastocystes du rat en l'absence d'hormones ovariennes. C.r. hebd. Séanc. Acad. Sci., Paris, 245, 1752.

Chambon, Y. (1949) Réalisation du retard de l'implantation par des faibles doses de progestérone chez la ratte. C.r. Séanc. Soc. Biol. 143, 753.

Cochrane, R. L. \& Meyer, R. K. (1957) Delayed nidation in the rat induced by progesterone. Proc. Soc. exp. Biol. Med. 96, 155.

Deanesty, R. (1966) The endocrinology of pregnancy and foetal life. In: Marshall's Physiology of Reproduction, 3rd edn., vol. 3, p. 891. Ed. A. S. Parkes. Longmans, Green, London.

Dickmann, Z. \& De Feo, V.J. (1967) The rat blastocyst during normal pregnancy and during delayed implantation, including an observation on the shedding of the zona pellucida. F. Reprod. Fert. $13,3$.

MAYER, G. (1963) Delayed nidation in rats: a method of exploring the mechanisms of ovo-implantation. In: Delayed Implantation, p. 213. Ed. A. C. Enders. University of Chicago Press.

Mayer, G., Thévenot-Duluc, A. \& Meunier, J. (1958) Action chez la ratte de différents équilibres hormonaux sur l'ovo-implantation et la vie latent de l'œuf. C.r. Séanc. Acad. Sci., Paris, 246, 1911.

MeYer, R. K. \& Nutting, E. F. (1964) Effect of combinations of progesterone and oestrone on the delay of nidation, implantation and foetal survival in ovariectomized rats. F. Endocr. 29, 243.

NUTTING, E. F. \& MEYER, R. K. (1963) Implantation delay, nidation, and embryonal survival in rats treated with ovarian hormones. In: Delayed Implantation, p. 233. Ed. A. C. Enders. University of Chicago Press.

Psychoyos, A. (1960) Nouvelle contribution à l'étude de la nidation de l'œuf chez la ratte. C.r. hebd. Séanc. Acad. Sci., Paris, 251, 3073.

SmithberG, M. \& RunNER, M. N. (1960) Retention of blastocysts in nonprogestational uteri of mice. 7. exp. Zool. 143, 21 .

Wertraur, H. (1968) The survival of blastocysts in the nonprogestational uteri of adult mice. Anat. Rec. 160,449 . 